\title{
A Pilot Study with Randomised Controlled Design Comparing TiZr Alloy Dental Implants to Ti Implants
}

\author{
Kristina Hultin $^{1}$, Annelie Eriksson ${ }^{1}$, Christina Backe ${ }^{2}$, Ulf Johansson ${ }^{2}$, Kostas Bougas $^{3}$ \\ ${ }^{1}$ Department of Prosthodontics, Södra Älvsborg Hospital, Borås, Sweden. \\ ${ }^{2}$ Department of Oral and Maxillofacial Surgery, Södra Älvsborg Hospital, Borås, Sweden. \\ ${ }^{3}$ Department of Periodontology, Södra Älvsborg Hospital, Borås, Sweden.
}

\author{
Corresponding Author: \\ Kristina Hultin \\ Department of Prosthodontics \\ Södra Älvsborgs Hospital \\ SE-50182 Borås \\ Sweden \\ Phone: +46104419590 \\ E-mail: kristina.e.hultin@vgregion.se
}

\begin{abstract}
Objectives: Evidence on the clinical performance of recently introduced dental implants in titanium-zirconium alloy is sparse. The aim of the present pilot study with randomized controlled design is to compare changes in supporting structures around dental titanium-zirconium alloy implants to commercially pure titanium implants.

Material and Methods: The present material includes consecutive patients referred to a specialist clinic in Sweden. Two patient groups treated with dental implants in two different materials - titanium (Ti) and titanium-zirconium (TiZr) - were defined after block randomisation for smoking. In total, 40 implants installed in 21 patients were available for one-year follow-up. Marginal bone level, soft tissue height and width of keratinised mucosa were registered at baseline and at one-year follow-up.

Results: At implant level, the test group (TiZr) yielded significant marginal bone loss $(\mathrm{P}<0.001)$ after one year. Additionally, marginal bone loss after one year was significantly higher for TiZr implants $(\mathrm{P}<0.001)$ as compared to traditional Ti implants. Soft tissue dimensions were stable throughout the evaluation time for both implant materials.

Conclusions: One-year results indicate more pronounced initial marginal bone loss for dental implants in titanium-zirconium alloy as compared to implants made of commercially pure titanium.
\end{abstract}

Keywords: bone resorption; dental implants; dental materials; titanium; zirconium.

\author{
Accepted for publication: 28 December 2020 \\ To cite this article: \\ Hultin K, Eriksson A, Backe C, Johansson U, Bougas K. \\ A Pilot Study with Randomised Controlled Design Comparing TiZr Alloy Dental Implants to Ti Implants \\ J Oral Maxillofac Res 2020;11(4):e3 \\ URL: http://www.ejomr.org/JOMR/archives/2020/4/e3/v11n4e3.pdf \\ doi: $\underline{10.5037 / j o m r .2020 .11403}$
}




\section{INTRODUCTION}

In the 1960s, Brånemark and co-workers [1] first presented dental implants and osseointegration as a reliable concept in treatment of edentulous patients. Since the introduction of dental implants titanium (Ti) grade 1 and gradually grade 4, also known as commercially pure $\mathrm{Ti}$ (cp-Ti), has been the golden standard when it comes to implant materials suitable for dental use. Properties as high strength, high resistance to corrosion, easy processing and favourable integration with surrounding bone tissue, contributes to its common use both in general medicine and in dental implantology [2]. Research has shown that treatment with dental implants made from $\mathrm{Ti}$ are predictable in terms of implant survival although the challenge is to keep patients enrolled in follow-up programs and to deal with technical and biological complications [3-5]. Nevertheless, the accumulated knowledge about Ti implants, as seen from 15- and 20-year followups, has been based on prerequisites that are not always followed today. One of them is that dental implants are not always made from cp-Ti. New materials have been studied as alternatives to the well-documented implant material $\mathrm{Ti}[\underline{6}, \underline{7}]$, with a focus on finding a material with increased mechanical strength combined with improved biological characteristics. Unfortunately, the mechanical strength can be insufficient and narrow diameter Ti implants have been associated with increased risk of fatigue fractures especially in areas with high load or in patients with parafunctional habits [ㅇ-10].

Alloys including $\mathrm{Ti}$, incorporating non-toxic elements such as zirconium $(\mathrm{Zr})$, niobium $(\mathrm{Nb})$, tantalum $(\mathrm{Ta})$, palladium (Pd) and indium (In), are being explored for their ability to match or increase the mechanical strength and corrosion resistance of Ti, with improved biocompatibility [11]. Ti alloys including aluminium (Al) (Ti6Al4V) which present better mechanical properties under cyclic loading relative to $\mathrm{cp}-\mathrm{Ti}$ [12]. However, creating sufficient surface roughness on Ti6Al4V implants has been challenging leading to concerns regarding material biocompatibility $[\underline{13}, \underline{14}]$. $\mathrm{Ti}$ and $\mathrm{Zr}$ are both transition metals in the same group of the periodic table and have similar chemical properties. An insoluble oxide layer is formed on the surface of both materials upon contact with oxygen, thereby enhancing their anticorrosive properties [15] thereby making them interesting for dental implant applications.

The aim of the present randomized controlled pilot study is to compare the clinical performance of titanium-zirconium alloy implants to commercially pure titanium implants with emphasis on hard and soft tissue-oriented outcomes after 1 year.

\section{MATERIAL AND METHODS}

The study was registered in online clinical trials register system www.clinicaltrials.gov and can be accessed with number NCT02681250.

Ethical approval has been acquired by the National Board of Review, Gothenburg, Western Sweden (reference number 216-15).

\section{Patient recruitment}

The present material represents a pilot study including 23 consecutive patients in need of dental implant treatment referred to the Department of Prosthodontics in Borås, Sweden from October 2015 to November 2016. In order to increase the study relevance for everyday clinical practice, several prosthetic protocols were included. No patients with history of periodontitis were included in the study. Patients belonging to the American Society of Anesthesiologists (ASA) class 4 (e.g., myocardial infarction or thrombotic episode within the last three months) [16]. Before entering the study, every patient had to sign a document of informed consent. If needed, hygiene instructions and cooperation control on individual basis were performed before starting the treatment. The following patient-related variables were assessed:

- Gender (male/female);

- Age (years);

- Smoking habits (yes/no);

- Number of cigarettes/day ( 0 to 10,0 to 20 and $>20$ ).

General health status and medication were also reported (Table 1).

The patients underwent block randomisation for smoking (K.H.) since smoking is a known risk factor for implant treatment $[\underline{17}, \underline{18}]$. Tissue level implants (Institute Straumann ${ }^{\circledR}$ AG; Basel, Switzerland) with sandblasted and acid-etched surface (Straumann $^{\circledR}$ $\left.\mathrm{SLA}^{\circledR}\right)$ were installed. The test group received TiZr alloy with 13 - 17\% Zr (TiZr1317) implants (Straumann $^{\circledR}$ Tissue Level Standard Plus SLA ${ }^{\circledR}$ Roxolid $^{\circledR}$ ) and the control group dental cp-Ti implants (Straumann ${ }^{\circledR}$ Tissue Level Standard Plus SLA $\left.^{\circledR}\right)$. 
Table 1. Distribution of implant characteristics

\begin{tabular}{|c|c|c|c|c|}
\hline \multirow{2}{*}{\multicolumn{2}{|c|}{ Implant characteristics }} & \multicolumn{2}{|c|}{$\begin{array}{l}\text { Implant } \\
\text { material }\end{array}$} & \multirow{2}{*}{$\begin{array}{c}\text { Total } \\
\text { (n) }\end{array}$} \\
\hline & & $\begin{array}{l}\text { Ti } \\
(\mathbf{n}) \\
\end{array}$ & $\begin{array}{c}\text { TiZr } \\
\text { (n) }\end{array}$ & \\
\hline \multirow{4}{*}{$\begin{array}{l}\text { Position in } \\
\text { jaw }\end{array}$} & Anterior maxilla (\#13-23) & 1 & 4 & 5 \\
\hline & $\begin{array}{l}\text { Posterior maxilla (\#14-17, } \\
\# 24-27 \text { ) }\end{array}$ & 4 & 7 & 11 \\
\hline & Anterior mandible (\#33-43) & 0 & 2 & 2 \\
\hline & $\begin{array}{l}\text { Posterior mandible (\#34- } \\
37, \# 44-47 \text { ) }\end{array}$ & 11 & 11 & 22 \\
\hline \multirow{3}{*}{$\begin{array}{l}\text { Implant } \\
\text { length }\end{array}$} & $8 \mathrm{~mm}$ & 3 & 2 & 5 \\
\hline & $10 \mathrm{~mm}$ & 11 & 16 & 27 \\
\hline & $12 \mathrm{~mm}$ & 2 & 6 & 8 \\
\hline \multirow{3}{*}{$\begin{array}{l}\text { Implant } \\
\text { diameter }\end{array}$} & $3.3 \mathrm{~mm}$ & 1 & 6 & 7 \\
\hline & $4.1 \mathrm{~mm}$ & 15 & 15 & 30 \\
\hline & $4.8 \mathrm{~mm}$ & 0 & 3 & 3 \\
\hline \multirow{2}{*}{$\begin{array}{l}\text { Abutment } \\
\text { use }\end{array}$} & Abutment & 13 & 24 & 37 \\
\hline & No abutment & 3 & 0 & 3 \\
\hline \multirow{2}{*}{ Anchorage } & Screw retained & 15 & 24 & 39 \\
\hline & Cemented & 0 & 1 & 1 \\
\hline \multirow{3}{*}{$\begin{array}{l}\text { Type of } \\
\text { restoration }\end{array}$} & Single crown & 6 & 9 & 15 \\
\hline & Partial bridge & 10 & 11 & 21 \\
\hline & Full arch bridge & 0 & 4 & 4 \\
\hline
\end{tabular}

$\mathrm{n}=$ number

\section{Clinical procedures}

Surgery was performed by two experienced surgeons (C.B., U.J.), at the Department of Oral and Maxillofacial Surgery in Borås, Sweden. Implant installation was performed according to the standard surgical protocol recommended from the manufacturer. Delayed loading protocol was employed in all cases. Impressions were made in polyether impression material (Impregum $^{\mathrm{TM}}$ DuoSoft ${ }^{\mathrm{TM}}, 3 \mathrm{M}^{\mathrm{TM}} \mathrm{ESPE}^{\mathrm{TM}}$, for single crowns and partial dentures and Impregum ${ }^{\mathrm{TM}}, 3 \mathrm{M}^{\mathrm{TM}}$ ESPETM, $^{\mathrm{TM}}$ for full arch impressions). All abutments were made in Ti. Prosthesis material varied and was either metal ceramic (cobalt-chromium with veneering porcelain), yttrium-stabilised tetragonal zirconium dioxide (with or without veneering porcelain) or (for the full arch prosthesis) $\mathrm{Ti}$ framework with acrylic veneering. Prosthesis screw torque was set according to manufacturer's instruction. Individually tailored oral hygiene instructions were given by a dental hygienist and the patients were recalled after 1 year.

\section{Radiographic examination}

Postoperative radiographic examinations were

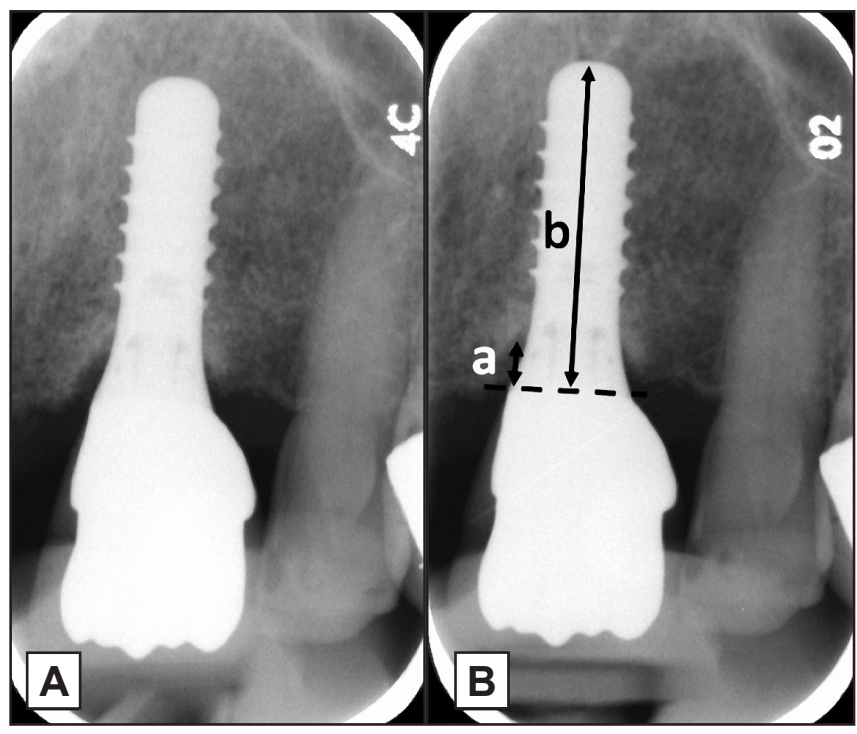

Figure 1. Postoperative standardised periapical radiographs: $\mathrm{A}=$ baseline $\mathrm{X}$-ray; $\mathrm{B}=$ follow-up $\mathrm{X}$-ray $(\mathrm{a}=$ marginal bone level; $\mathrm{b}=$ calibration measure).

performed upon delivery of the permanent restoration (baseline) and at follow-up examinations at 1 year. Standardised periapical radiographs were taken using film holders (Have-Super-Bite ${ }^{\mathrm{TM}}$ - HaweNeos Dental; Genilino, Switzerland) and digital imaging plate system (Vistascan ${ }^{\circledR}$ - Dürr Dental AG; Bietigheim-Bissingen, Germany) with the X-ray beam perpendicular to the implant. The film holder device was attached to the occlusal surface of the supraconstruction using a putty silicone impression material (Flexitime $^{\circledR}$ Easy Putty - Heraeus Kulzer; Hanau, Germany) to ensure that the film holder position can be repeated at the follow-up visit $[19,20]$.

The radiographs were evaluated regarding marginal bone level. Interexaminer reliability $(\mathrm{KH}, \mathrm{AE})$ was performed in terms of calibration at 10 randomly selected implants. All measurements were made in Romexis $^{\circledR}$ software (Planmeca Romexis ${ }^{\circledR}$, Helsinki, Finland). Before measurements were made, implants were calibrated in the software according to the known length of the individual implant. The distance between the implant reference point (implant shoulder) to the marginal bone was recorded (Figure 1). The mean value of the two interproximal aspects of the implant was reported as primary outcome.

\section{Clinical examination}

At baseline and after 1 year in function, the following parameters were recorded:

- Type of implant material (TiZr/Ti);

- Position of the implant;

- Type of prosthodontics (single crown/partial bridge/full arch bridge);

- Number of implants included in the prostheses; 
- Use of abutment (yes/no);

- Connection type of the prosthesis (screw retained/ cemented);

- Implant length (mm);

- Implant diameter ( $\mathrm{mm}$ ).

The vertical dimension of the mucosa was registered with a periodontal probe (Hu-Friedy Mfg. Co., LLC; Frankfurt, Germany) and was assessed from the bottom of pocket to the mucosal margin at the mesial, distal, palatal/lingual and buccal site $(\mathrm{mm})$ [21]. The width of the keratinised mucosa $(\mathrm{mm})$ was registered with the periodontal probe from the mucosal margin to the most apical part of keratinised mucosa at the buccal side of the implant. Clinical measurements were performed by the same clinician $(\mathrm{KH})$ at all follow-ups.

\section{Statistical analysis}

The statistical analysis was performed with SPSS Statistics version 22 (SPSS Inc.; Chicago, Illinois, USA). The primary outcome was alteration in marginal bone level from baseline to the one-year examination. Alterations in marginal bone level, soft tissue height and width of the keratinised mucosa were assessed. An overview of the present patient material and alterations in marginal bone level is presented with descriptive statistics at patient- and implant level (Figure 2 and 3). Two-way mixed model was used for estimating inter-examiner reliability resulting to a correlation coefficient of 0.95. Paired samples t-test was used to compare alterations in marginal bone levels, vertical dimension peri-implant mucosa and the width of the keratinised mucosa within each implant group. The intergroup alterations in marginal bone level were compared by using t-test. Pearson correlations test was used for testing of correlation between width of keratinised mucosa and marginal bone loss. P-values $\leq 0.05$ were considered statistically significant. Parametric data were expressed as mean and standard deviation (M [SD]).

\section{RESULTS}

In total, 23 patients were included in the study and randomized into two groups $(\mathrm{Ti}=11, \mathrm{TiZr}=12)$. Two patients, one from each group were considered as drop outs; one patient received another implant design due to aesthetic considerations and one patient did not attend the follow-up visit. In total, 21 patients $(\mathrm{Ti}=10, \mathrm{TiZr}=11)$ completed the 1 -year followup rendering a drop-out rate of $8.7 \%$. Given the low and equally distributed dropout rate, a per-protocol analysis was implemented.

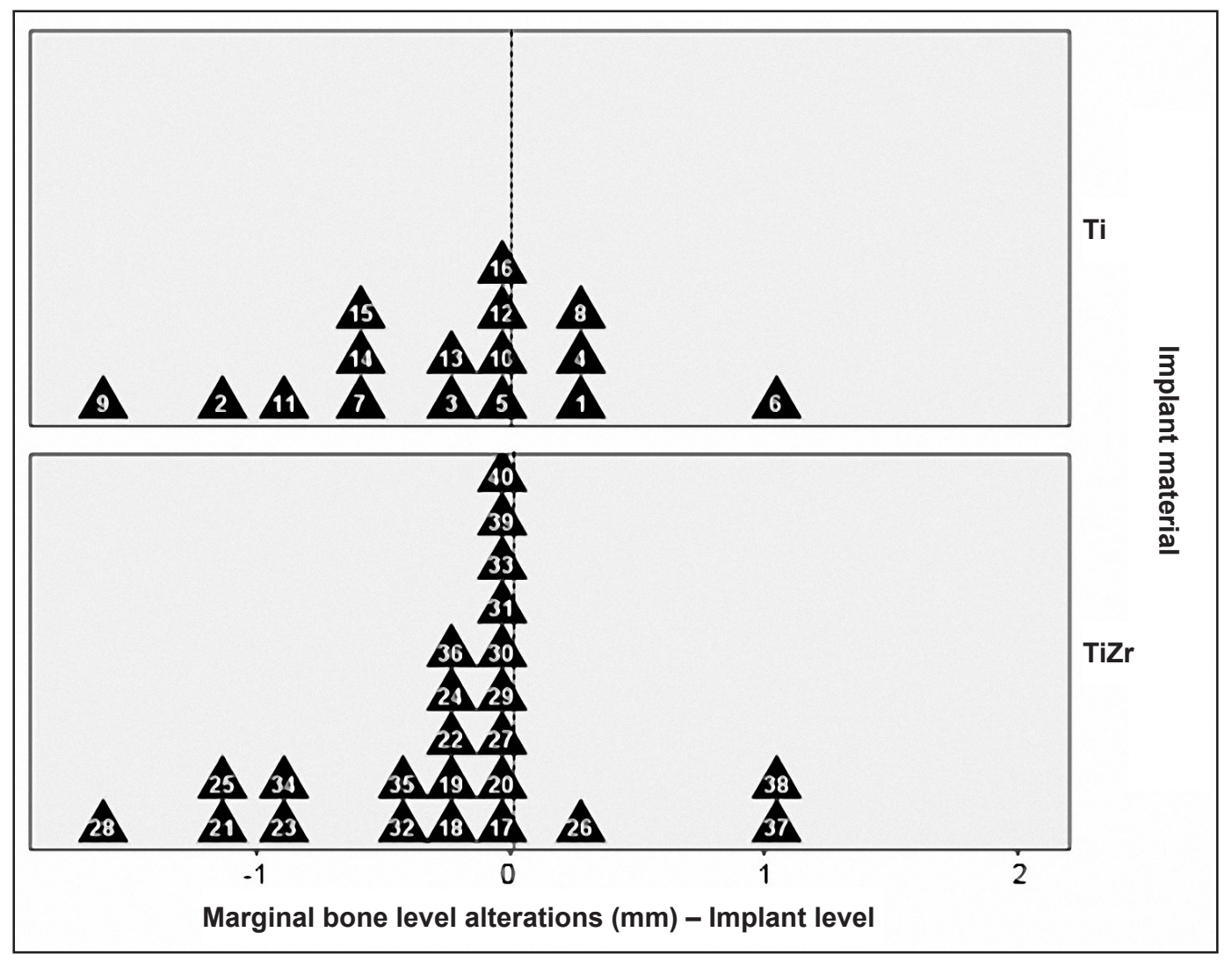

Figure 2. Marginal bone level alterations (numbers displaying implant). 


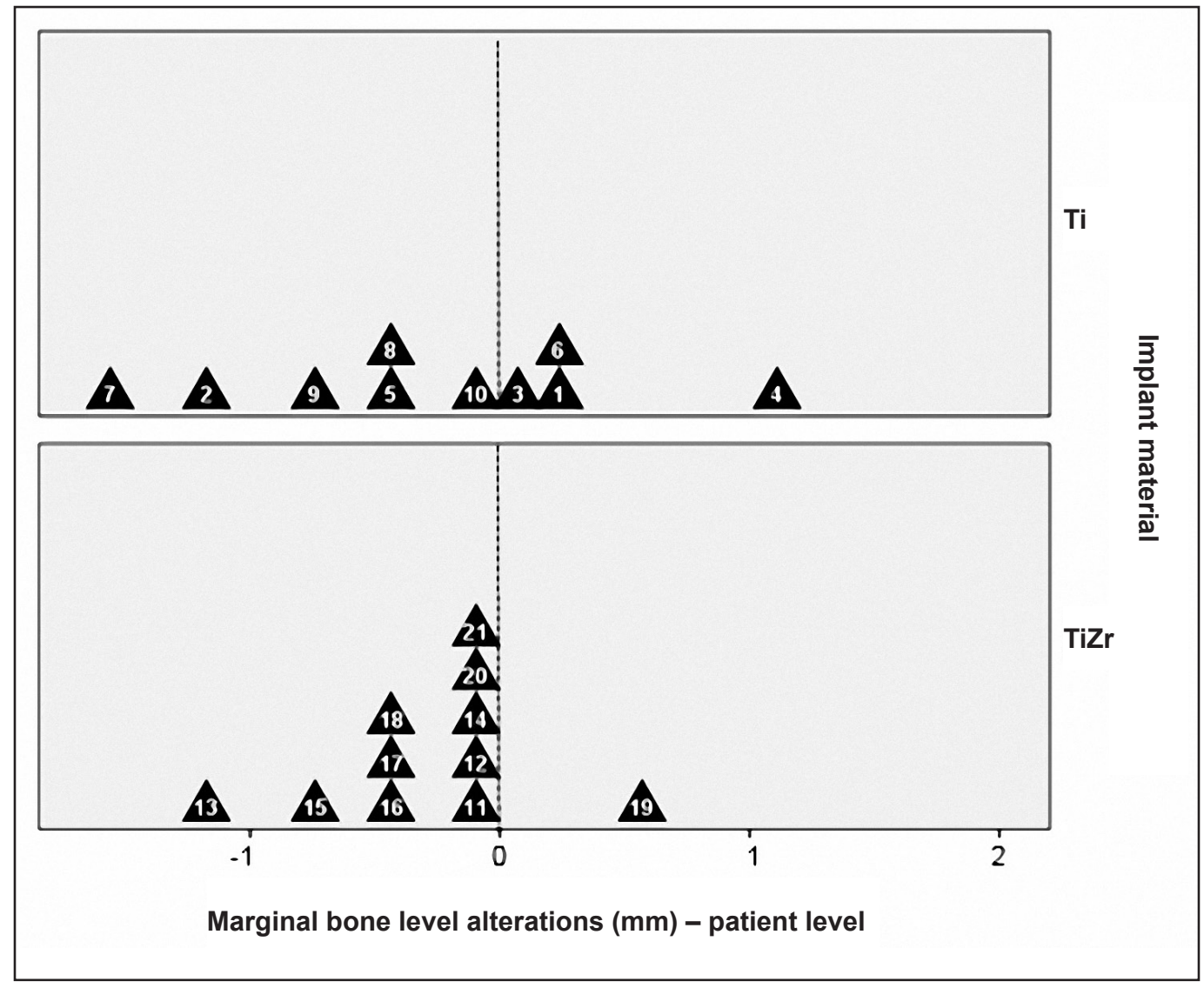

Figure 3. Marginal bone level alterations (numbers displaying patient).

Forty implants $(\mathrm{Ti}=16, \mathrm{TiZr}=24)$ were installed in 13 males and 8 females $(\mathrm{Ti}=5$ males $/ 5$ females, TiZr $=8$ males $/ 3$ females). The mean age was 42.5 (23.8) years in the control group and 54.6 (19.2) years in the test group. Five patients $(\mathrm{Ti}=2$, $\mathrm{TiZr}=3$ ) were smokers at the time of surgery, all in group " 0 - 10 cigarettes/day", no patients reported more than 10 cigarettes/day. Patient related characteristics are presented in Table 2.

Fifteen implants supported single crowns $(\mathrm{Ti}=6$, TiZr = 9), 21 implants supported partial bridges $(\mathrm{Ti}=10, \mathrm{TiZr}=11)$, and four implants supported one full arch bridge $(\mathrm{Ti}=0, \mathrm{TiZr}=4)$. Only one restoration (single crown) in the test group (TiZr) was cemented, all other restorations were screw retained. Implant related characteristics are presented in Table 2. The mean diameter in the test and control group was $3.99 \mathrm{~mm}$ and 4.05 respectively. The mean implant length was $10.33 \mathrm{~mm}$ and $9.88 \mathrm{~mm}$ respectively.

\section{Marginal bone level}

Paired samples t-test for the control group (Ti) revealed no significant alterations in marginal bone level at implant level $(\mathrm{P}=0.12)$ (Table 3, Figure 2). However, the test group (TiZr) demonstrated significant bone loss $(\mathrm{P}<0.001)$
Table 2. Distribution of patient characteristics

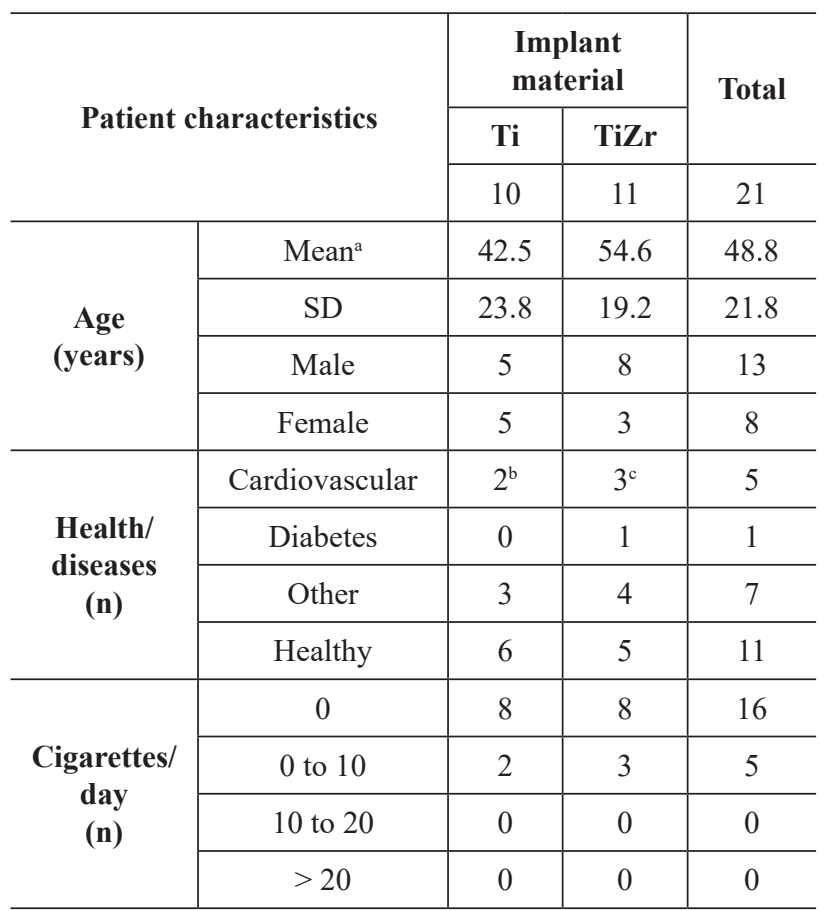

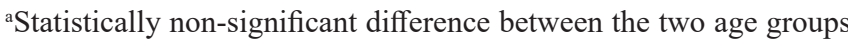
$(\mathrm{P}=0.22)$.

'One subject with "cardiovascular" and "other" diseases.

"One subject with "cardiovascular" and "other" diseases and one subject with "cardiovascular" and "diabetes".

$\mathrm{n}=$ number; $\mathrm{SD}=$ standard deviation . 
Table 3. Alterations in marginal bone level, vertical dimensions of the soft tissue and keratinized mucosa

\begin{tabular}{|c|c|c|c|}
\hline & \multicolumn{3}{|c|}{ Paired differences } \\
\hline & Mean & SD & P-value \\
\hline \multicolumn{4}{|c|}{ Alterations in marginal bone level, MBL (mm) - implant level } \\
\hline Ti MBL. Baseline - Ti MBL 1 year & -0.27 & 0.64 & 0.12 \\
\hline TiZr MBL. Baseline - TiZr MBL 1 year & -0.98 & 1.01 & $<0.001$ \\
\hline \multicolumn{4}{|c|}{ Alterations in marginal bone level, MBL (mm) - patient level } \\
\hline Ti MBL. Baseline - Ti MBL 1 year & -0.27 & 0.63 & 0.21 \\
\hline TiZr MBL. Baseline - TiZr MBL 1 year & -0.19 & 0.61 & 0.32 \\
\hline \multicolumn{4}{|c|}{ Alterations in vertical dimension of the soft tissue $(\mathrm{mm})$ - implant level } \\
\hline Ti. Baseline - Ti 1 year & -0.31 & 0.6 & 0.06 \\
\hline TiZr. Baseline - TiZr 1 year & 0.02 & 0.57 & 0.86 \\
\hline \multicolumn{4}{|c|}{ Alterations in keratinized mucosa $(\mathrm{mm})$ - implant level } \\
\hline Both groups. Baseline - 1 year & -0.15 & 0.87 & 0.28 \\
\hline
\end{tabular}

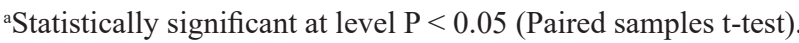

$\mathrm{MBL}=$ marginal bone level; $\mathrm{SD}=$ standard deviation.

between baseline and one year (Table 3, Figure 2) on implant level. The marginal bone loss for $\mathrm{TiZr}$ implants was significantly higher as compared to the control group $(\mathrm{P}<0.001)$. At patient level, the alterations in marginal bone level were not significant (TiZr: $\mathrm{P}=0.32$, Ti: $\mathrm{P}=0.21$ ), (Figure 3 , Table 3 ). It was concluded that the change in marginal bone level was independent of the width of the keratinised mucosa at baseline $(\mathrm{P}=0.81)$.

\section{Soft tissue}

The vertical dimension of the soft tissue surrounding the implants was stable throughout the evaluation time for both implant materials (Ti: $\mathrm{P}=0.06$, TiZr: $\mathrm{P}=0.86$ ) (Table 3). The amount of keratinised mucosa surrounding the implants did not change significantly in neither of groups during the evaluation period $(\mathrm{P}=0.28)$ (Table 3).

\section{DISCUSSION}

The results of the present pilot study suggest that sandblasted and acid-etched TiZr alloy implants present more pronounced initial marginal bone loss as compared to implants in $\mathrm{cp}-\mathrm{Ti}$ with corresponding surface modification. The vertical dimensions of the soft tissues surrounding the implants seem to be stable over the follow-up period regardless the implant material. Additionally, the initial marginal bone loss seems to be independent of the width of keratinised mucosa at baseline.
Currently, research on dental implants in TiZr alloy is limited [22] and consists mainly of animal studies and a few clinical studies $[23,24]$ by which only a few have comparative design [25-27]. Although the first study in humans was published in 2011 [28], no results are available with more than five years of clinical follow-up [25].

The objective of the present study was to compare two core materials having been subjected to the same surface treatment modality, i.e. large grit blasting and acid-etching. It is evident that surface topography and chemistry affect the osseointegration process [29-31]. It has been demonstrated that due to the monophasic alphastructure of TiZr1317, microtopography is developed by acid-etching and sandblasting $[\underline{32}, \underline{33}]$. However, some differences in microtopography have been observed between cp-Ti and TiZr after acid-etching and sandblasting. An in vitro study by Frank et al. [33] comparing sandblasted and acid-etched discs in cp-Ti and $\mathrm{TiZr}$ demonstrated significant differences on micro- and nanotopography. Wennerberg et al. [34] concluded in vitro that hydrophilic, sandblasted and acid-etched (SLA-activemodified) Ti discs presented higher mean surface roughness $(\mathrm{Sa})$, lower density of surface summit (Sds) and higher total surface exposed to bone (Sdr) as compared to TiZr. Similar results were presented in an animal study by Jimbo et al. [35] The authors compared the surface topography of cp-Ti SLActive ${ }^{\circledR}$ and TiZr SLActive ${ }^{\circledR}$ implants and found that average height deviation was similar, but the TiZr implants were overall less rough, as the Sds and the Sdr were significantly smaller compared to the cp-Ti implants [35]. 
A proposed explanation model for the different clinical outcomes may be found in a study by Lotz et al. [36]. In this in vitro study it was concluded that human osteoblasts cultured on SLActive ${ }^{\circledR}$ modified TiZr discs presented lower gene expressions of IL-6 and BMP-4 as compared to Ti discs. IL- 6 is a proinflammatory marker considered to be important in bone formation in conditions of high bone turnover [37]. Since inflammation is proved to be concomitant to bone formation [38], it is reasonable to assume that lower levels of IL-6 imply lower rate of bone formation. Furthermore, lower expression of BMP4 may denote lower osteogenic capacity for $\mathrm{TiZr}$ surfaces as compared to Ti. Our study revealed a significant difference in marginal bone loss at implant level from baseline to one year follow-up in the TiZr group but not in the Ti group which can be interpreted as the core material might have an impact on the osseointegration process.

Gottlow et al. [39] presented results from an animal study comparing TiZr implants to implants made from commercially pure Ti in 12 mini pigs. Although similar osteoconductive properties in terms of bone-to-implant-contact were demonstrated, TiZrimplants were associated with significantly higher stability compared to implants made from cp-Ti [39]. However, other animal studies have failed to demonstrate improved biological and mechanical properties of dental implants made from TiZr1317 as compared to $\mathrm{cp}-\mathrm{Ti}[\underline{40}, \underline{41}]$.

Benic et al. [42] presented one-year results from a human randomized controlled clinical study on 40 single implants in anterior and premolar region comparing $3.3 \mathrm{~mm}$ Straumann ${ }^{\circledR}$ TiZr SLActive ${ }^{\circledR}$ to $4.1 \mathrm{~mm}$ Straumann $^{\circledR}$ Ti SLActive ${ }^{\circledR}$ implants. No differences between the two core materials regarding change in marginal bone loss, clinical parameters and the occurrence of adverse events were evident [42]. Three-year results from the same patient material no significant differences in either change in marginal bone level, change in mucosa levels or occurrence of complications could be proved [26]. In another randomized multicenter clinical trial on implant supported overdentures with split mouth design, narrow diameter implants in TiZr and cp-Ti were compared [25]. The study had high dropout rate since 49 of 91 patients fulfilled the study to the five-year follow-up. No differences in terms of marginal bone loss or mucosal health could be concluded from that study. Tolentino et al. [27] presented the results from a small randomized study in split mouth design on narrow diameter implants in TiZr compared to cp-Ti supporting single crowns in molar region in a one year follow-up. The surface treatment on the TiZr implant was not reported. No differences in marginal bone loss or mucosal health were concluded [27].

The current study presents unfavourable results for TiZr implants in terms of increased marginal bone loss over the one year follow-up. Since soft tissue integration has gained increasing attention as a tentative factor influencing implant success, it is reasonable to assume that implant core material may affect soft tissue healing and integration. In the present study, the one-piece implant design contributes with a study model exposing the same implant core material against both hard and soft tissues. However, the results of the current study yield no significant changes in the vertical soft tissue dimension in neither the Ti nor the TiZr implant group over the one year observation period. These results are in agreement with five year clinical results comparing implants in $\mathrm{cp}-\mathrm{Ti}$ and TiZr $[\underline{25}, \underline{27}]$. The penetrating mucosal part of the Straumann ${ }^{\circledR}$ Tissue Level implants has a machined/polished surface with no additional surface modification. Since the machining process gives raise to similar surface characteristics for both cp-Ti and TiZr [33], it may be speculated that both implant materials may result to similar soft tissue responses. Zhang et al. [11] could not reveal any differences in growth of human fibroblasts on machined TiZr alloy discs as compared to machined cp-Ti discs in a laboratory study [43] $]$. Similar results could be concluded in a comparable study by GomezFlorit et al. [44]. These results are in line with the results from this current clinical study.

Since the participants of the current study were recruited in a consecutive basis, some general conditions may have affected the study outcome. Smoking and poorly controlled diabetes are known patient-related factors that may influence the long-term stability of peri-implant tissues [17,45]. However, a recent 5-year follow-up [46] concluded that smoking had no effect on peri-implant tissues surrounding Ti- or TiZr-implants, concomitantly highlighting the role of routine oral hygiene maintenance. Also, when it comes to patients with well-controlled diabetes mellitus type 2 , the prognosis for TiZr-implants seems to be equally good as for subjects with normal glycemic level [47].

Although it has been suggested that dental implants require a soft tissue barrier to prevent bacterial penetration [48], the need for keratinised mucosa surrounding dental implants in order to guarantee long term success is still unclear $[49,50]$. Chung et al. [51] found no correlation between the presence of keratinised mucosa and annual bone loss. Nevertheless, the findings supported a correlation between absence of keratinised mucosa and higher plaque accumulation and gingival inflammation [51]. 
In a long term follow-up of 58 implant patients treated with guided bone regeneration no evidence was found that the width of keratinised mucosa is a predictor for bone loss [52]. Correlation analysis in our study suggested no significant correlation between the width of keratinised mucosa at baseline and the alterations of marginal bone level.

\section{CONCLUSIONS}

Despite the limitations of this pilot study in terms of mixed implants diameters and prosthetic protocols, the one-year results indicate more pronounced initial marginal bone loss for titanium zirconium alloy with $13-17 \%$ zirconium implants as compared to implants made from commercially pure titanium. These results, in combination with the absence of other large scale studies in this narrow scientific field, advocate the need for larger scale studies in order to be able to clarify any differences in maintaining a stable marginal bone level around the two implant types. However, the vertical dimensions of the peri-implant soft tissue seem to be stable over the follow-up period regardless of the implant material. Additionally, the width of keratinised mucosa at baseline seems not to influence marginal bone level.

\section{ACKNOWLEDGMENTS AND DISCLOSURE STATEMENTS}

The current study was in financially supported by the Research and Development Division of the County of Västra Götaland, Sweden.

Dr. Kostas Bougas has financial relationships with Straumann ${ }^{\circledR}$ resulting from speaking engagements. Remaining authors report no conflict of interest related to this study.

\section{REFERENCES}

1. Brånemark PI, Adell R, Breine U, Hansson BO, Lindström J, Ohlsson A. Intra-osseous anchorage of dental prostheses. I. Experimental studies. Scand J Plast Reconstr Surg. 1969;3(2):81-100. [Medline: 4924041] [doi: 10.3109/02844316909036699]

2. Brånemark PI. Osseointegration and its experimental background. J Prosthet Dent. 1983 Sep;50(3):399-410. [Medline: 6352924] [doi: 10.1016/S0022-3913(83)80101-2]

3. Ekelund JA, Lindquist LW, Carlsson GE, Jemt T. Implant treatment in the edentulous mandible: a prospective study on Brånemark system implants over more than 20 years. Int J Prosthodont. 2003 Nov-Dec;16(6):602-8. [Medline: 14714838]

4. Jemt T. Single-Implant Survival: More Than 30 Years of Clinical Experience. Int J Prosthodont. 2016 Nov/Dec;29(6): 551-558. [Medline: 27824972] [doi: 10.11607/ijp.4892]

5. Jung RE, Zembic A, Pjetursson BE, Zwahlen M, Thoma DS. Systematic review of the survival rate and the incidence of biological, technical, and aesthetic complications of single crowns on implants reported in longitudinal studies with a mean follow-up of 5 years. Clin Oral Implants Res. 2012 Oct;23 Suppl 6:2-21. [Medline: 23062124] [doi: 10.1111/j.1600-0501.2012.02547.x]

6. Bougas K, Jimbo R, Vandeweghe S, Hayashi M, Bryington M, Kozai Y, Schwartz-Filho HO, Tovar N, Adolfsson E, Ono D, Coelho PG, Wennerberg A. Bone apposition to laminin-1 coated implants: histologic and 3D evaluation. Int J Oral Maxillofac Surg. 2013 May;42(5):677-82. [Medline: 23228694] [doi: 10.1016/j.ijom.2012.11.008]

7. Johansson P, Barkarmo S, Hawthan M, Peruzzi N, Kjellin P, Wennerberg A. Biomechanical, histological, and computed X-ray tomographic analyses of hydroxyapatite coated PEEK implants in an extended healing model in rabbit. J Biomed Mater Res A. 2018 May;106(5):1440-1447. [Medline: 29341426] [doi: 10.1002/jbm.a.36345]

8. Romeo E, Lops D, Amorfini L, Chiapasco M, Ghisolfi M, Vogel G. Clinical and radiographic evaluation of smalldiameter (3.3-mm) implants followed for 1-7 years: a longitudinal study. Clin Oral Implants Res. 2006 Apr;17(2):139-48. [Medline: 16584409] [doi: 10.1111/j.1600-0501.2005.01191.x]

9. Allum SR, Tomlinson RA, Joshi R. The impact of loads on standard diameter, small diameter and mini implants: a comparative laboratory study. Clin Oral Implants Res. 2008 Jun;19(6):553-9. [Medline: 18474061] [doi: 10.1111/j.1600-0501.2007.01395.x]

10. Schwarz MS. Mechanical complications of dental implants. Clin Oral Implants Res. 2000;11 Suppl 1:156-8. [Medline: 11168264] [doi: 10.1034/j.1600-0501.2000.011S1156.x]

11. Zhang YM, Chai F, Hornez JC, Li CL, Zhao YM, Traisnel M, Hildebrand HF. The corrosion and biological behaviour of titanium alloys in the presence of human lymphoid cells and MC3T3-E1 osteoblasts. Biomed Mater. 2009 Feb;4(1): 015004. [Medline: 18981540] [doi: 10.1088/1748-6041/4/1/015004]

12. Niinomi M. Mechanical biocompatibilities of titanium alloys for biomedical applications. J Mech Behav Biomed Mater. 2008 Jan;1(1):30-42. [Medline: 19627769] [doi: 10.1016/j.jmbbm.2007.07.001]

13. Khan MA, Williams RL, Williams DF. Conjoint corrosion and wear in titanium alloys. Biomaterials. 1999 Apr;20(8): 765-72. doi: 10.1016/s0142-9612(98)00229-4. [Medline: 10353659] [doi: 10.1016/S0142-9612(98)00229-4] 
14. Cointry GR, Capozza RF, Negri AL, Ferretti JL. Biomechanical impact of aluminum accumulation on the preand post-yield behavior of rat cortical bone. J Bone Miner Metab. 2005;23(1):15-23. [Medline: 15616889] [doi: 10.1007/s00774-004-0535-x]

15. Kobayashi E, Matsumoto S, Doi H, Yoneyama T, Hamanaka H. Mechanical properties of the binary titanium-zirconium alloys and their potential for biomedical materials. J Biomed Mater Res. 1995 Aug;29(8):943-50. [Medline: 7593037] [doi: $10.1002 / \mathrm{jbm} .820290805$ ]

16. Mayhew D, Mendonca V, Murthy BVS. A review of ASA physical status - historical perspectives and modern developments Anaesthesia. 2019 Mar;74(3):373-379. [Medline: 30648259] [doi: 10.1111/anae.14569]

17. Chrcanovic BR, Albrektsson T, Wennerberg A. Smoking and dental implants: A systematic review and meta-analysis. J Dent. 2015 May;43(5):487-98. [Medline: 25778741] [doi: 10.1016/j.jdent.2015.03.003]

18. Derks J, Håkansson J, Wennström JL, Tomasi C, Larsson M, Berglundh T. Effectiveness of implant therapy analyzed in a Swedish population: early and late implant loss. J Dent Res. 2015 Mar;94(3 Suppl):44S-51S. [Medline: 25503901] [PMC free article: 4541089] [doi: 10.1177/0022034514563077]

19. Nicolau P, Korostoff J, Ganeles J, Jackowski J, Krafft T, Neves M, Divi J, Rasse M, Guerra F, Fischer K. Immediate and early loading of chemically modified implants in posterior jaws: 3-year results from a prospective randomized multicenter study. Clin Implant Dent Relat Res. 2013 Aug;15(4):600-12. [Medline: 22171722] [doi: $10.1111 / \mathrm{j} .1708-8208.2011 .00418 . x$ ]

20. Wennström JL, Ekestubbe A, Gröndahl K, Karlsson S, Lindhe J. Implant-supported single-tooth restorations: a 5-year prospective study. J Clin Periodontol. 2005 Jun;32(6):567-74. [Medline: 15882213] [doi: 10.1111/j.1600-051X.2005.00715.x]

21. Renvert S, Persson GR, Pirih FQ, Camargo PM. Peri-implant health, peri-implant mucositis, and peri-implantitis: Case definitions and diagnostic considerations. J Clin Periodontol. 2018 Jun;45 Suppl 20:S278-S285. [Medline: 29926496] [doi: 10.1111/jepe.12956]

22. Badran Z, Struillou X, Strube N, Bourdin D, Dard M, Soueidan A, Hoornaert A. Clinical Performance of Narrow-Diameter Titanium-Zirconium Implants: A Systematic Review. Implant Dent. 2017 Apr;26(2):316-323. [Medline: 28114266] [doi: 10.1097/ID.0000000000000557]

23. Altuna P, Lucas-Taulé E, Gargallo-Albiol J, Figueras-Álvarez O, Hernández-Alfaro F, Nart J. Clinical evidence on titaniumzirconium dental implants: a systematic review and meta-analysis. Int J Oral Maxillofac Surg. 2016 Jul;45(7):842-50. [Medline: 26852292] [doi: 10.1016/j.ijom.2016.01.004]

24. Iegami CM, Uehara PN, Sesma N, Pannuti CM, Tortamano Neto P, Mukai MK. Survival rate of titanium-zirconium narrow diameter dental implants versus commercially pure titanium narrow diameter dental implants: A systematic review. Clin Implant Dent Relat Res. 2017 Dec;19(6):1015-1022. [Medline: 28853215] [doi: 10.1111/cid.12527]

25. Müller F, Al-Nawas B, Storelli S, Quirynen M, Hicklin S, Castro-Laza J, Bassetti R, Schimmel M; Roxolid Study Group. Small-diameter titanium grade IV and titanium-zirconium implants in edentulous mandibles: five-year results from a double-blind, randomized controlled trial. BMC Oral Health. 2015 Oct 12;15(1):123. [Medline: 26458813] [PMC free article: 4603635] [doi: 10.1186/s12903-015-0107-6]

26. Ioannidis A, Gallucci GO, Jung RE, Borzangy S, Hämmerle CH, Benic GI. Titanium-zirconium narrow-diameter versus titanium regular-diameter implants for anterior and premolar single crowns: 3-year results of a randomized controlled clinical study. J Clin Periodontol. 2015 Nov;42(11):1060-70. [Medline: 26440201] [doi: 10.1111/jcpe.12468]

27. Tolentino L, Sukekava F, Garcez-Filho J, Tormena M, Lima LA, Araújo MG. One-year follow-up of titanium/zirconium alloy X commercially pure titanium narrow-diameter implants placed in the molar region of the mandible: a randomized controlled trial. Clin Oral Implants Res. 2016 Apr;27(4):393-8. [Medline: 25692479] [doi: 10.1111/clr.12561]

28. Chiapasco M, Casentini P, Zaniboni M, Corsi E, Anello T. Titanium-zirconium alloy narrow-diameter implants (Straumann Roxolid(®)) for the rehabilitation of horizontally deficient edentulous ridges: prospective study on 18 consecutive patients. Clin Oral Implants Res. 2012 Oct;23(10):1136-41. [Medline: 22092806] [doi: 10.1111/j.1600-0501.2011.02296.x]

29. Wennerberg A, Albrektsson T, Lausmaa J. Torque and histomorphometric evaluation of c.p. titanium screws blasted with 25- and 75-microns-sized particles of A12O3. J Biomed Mater Res. 1996 Feb;30(2):251-60. [Medline: 9019491$]$ [doi: 10.1002/(SICI)1097-4636(199602)30:23.0.CO;2-P]

30. Wennerberg A, Albrektsson T, Andersson B. Bone tissue response to commercially pure titanium implants blasted with fine and coarse particles of aluminum oxide. Int J Oral Maxillofac Implants. 1996 Jan-Feb;11(1):38-45. [Medline: $\underline{8820121]}$

31. Wennerberg A, Albrektsson T, Johansson C, Andersson B. Experimental study of turned and grit-blasted screw-shaped implants with special emphasis on effects of blasting material and surface topography. Biomaterials. 1996 Jan;17(1): 15-22. [Medline: 8962942] [doi: 10.1016/0142-9612(96)80750-2]

32. Medvedev AE, Molotnikov A, Lapovok R, Zeller R, Berner S, Habersetzer P, Dalla Torre F. Microstructure and mechanical properties of Ti-15Zr alloy used as dental implant material. J Mech Behav Biomed Mater. 2016 Sep;62: 384-398. [Medline: 27258932] [doi: 10.1016/j.jmbbm.2016.05.008]

33. Frank MJ, Walter MS, Lyngstadaas SP, Wintermantel E, Haugen HJ. Hydrogen content in titanium and a titaniumzirconium alloy after acid etching. Mater Sci Eng C Mater Biol Appl. 2013 Apr 1;33(3):1282-8. [Medline: 23827573] [doi: 10.1016/j.msec.2012.12.027] 
34. Wennerberg A, Svanborg LM, Berner S, Andersson M. Spontaneously formed nanostructures on titanium surfaces. Clin Oral Implants Res. 2013 Feb;24(2):203-9. [Medline: 22332922] [doi: 10.1111/j.1600-0501.2012.02429.x]

35. Jimbo R, Naito Y, Galli S, Berner S, Dard M, Wennerberg A. Biomechanical and Histomorphometrical Evaluation of TiZr Alloy Implants: An in vivo Study in the Rabbit. Clin Implant Dent Relat Res. 2015 Oct;17 Suppl 2:e670-8. [Medline: 25879834] [doi: 10.1111/cid.12305]

36. Lotz EM, Olivares-Navarrete R, Hyzy SL, Berner S, Schwartz Z, Boyan BD. Comparable responses of osteoblast lineage cells to microstructured hydrophilic titanium-zirconium and microstructured hydrophilic titanium. Clin Oral Implants Res. 2017 Jul;28(7):e51-e59. [Medline: 27273082] [doi: 10.1111/clr.12855]

37. Franchimont N, Wertz S, Malaise M. Interleukin-6: An osteotropic factor influencing bone formation? Bone. 2005 Nov;37(5):601-6. [Medline: 16112634] [doi: 10.1016/j.bone.2005.06.002]

38. Berglundh T, Abrahamsson I, Lang NP, Lindhe J. De novo alveolar bone formation adjacent to endosseous implants. Clin Oral Implants Res. 2003 Jun;14(3):251-62. [Medline: 12755774] [doi: 10.1034/j.1600-0501.2003.00972.x]

39. Gottlow J, Dard M, Kjellson F, Obrecht M, Sennerby L. Evaluation of a new titanium-zirconium dental implant: a biomechanical and histological comparative study in the mini pig. Clin Implant Dent Relat Res. 2012 Aug;14(4): 538-45. [Medline: 20586785] [doi: 10.1111/j.1708-8208.2010.00289.x]

40. Anchieta RB, Baldassarri M, Guastaldi F, Tovar N, Janal MN, Gottlow J, Dard M, Jimbo R, Coelho PG. Mechanical property assessment of bone healing around a titanium-zirconium alloy dental implant. Clin Implant Dent Relat Res. 2014 Dec;16(6):913-9. [Medline: 23527994] [doi: 10.1111/cid.12061]

41. Thoma DS, Jones AA, Dard M, Grize L, Obrecht M, Cochran DL. Tissue integration of a new titanium-zirconium dental implant: a comparative histologic and radiographic study in the canine. J Periodontol. 2011 Oct;82(10):1453-61. [Medline: 21961454] [doi: 10.1902/jop.2010.100737]

42. Benic GI, Gallucci GO, Mokti M, Hämmerle CH, Weber HP, Jung RE. Titanium-zirconium narrow-diameter versus titanium regular-diameter implants for anterior and premolar single crowns: 1-year results of a randomized controlled clinical study. J Clin Periodontol. 2013 Nov;40(11):1052-61. [Medline: 24015975] [doi: 10.1111/jcpe.12156]

43. Zhao B, van der Mei HC, Subbiahdoss G, de Vries J, Rustema-Abbing M, Kuijer R, Busscher HJ, Ren Y. Soft tissue integration versus early biofilm formation on different dental implant materials. Dent Mater. 2014 Jul;30(7):716-27. [Medline: 24793200] [doi: 10.1016/j.dental.2014.04.001]

44. Gómez-Florit M, Ramis JM, Xing R, Taxt-Lamolle S, Haugen HJ, Lyngstadaas SP, Monjo M. Differential response of human gingival fibroblasts to titanium- and titanium-zirconium-modified surfaces. J Periodontal Res. 2014 Aug;49(4):42536. [Medline: 23919718] [doi: 10.1111/jre.12121]

45. Al Zahrani S, Al Mutairi AA. Crestal Bone Loss Around Submerged and Non-Submerged Dental Implants in Individuals with Type-2 Diabetes Mellitus: A 7-Year Prospective Clinical Study. Med Princ Pract. 2019;28(1):75-81. [Medline: 30396170] [PMC free article: $\underline{6558320}$ ] [doi: 10.1159/000495111]

46. Alsahhaf A, Alshagroud RS, Al-Aali KA, Alofi RS, Vohra F, Abduljabbar T. Survival of Titanium-Zirconium and Titanium Dental Implants in Cigarette-smokers and Never-smokers: A 5-Year Follow-up. Chin J Dent Res. 2019;22(4):265-272. [Medline: 31859286] [doi: 10.3290/j.cjdr.a43737]

47. Cabrera-Domínguez JJ, Castellanos-Cosano L, Torres-Lagares D, Pérez-Fierro M, Machuca-Portillo G. Clinical performance of titanium-zirconium implants with a hydrophilic surface in patients with controlled type 2 diabetes mellitus: 2-year results from a prospective case-control clinical study. Clin Oral Investig. 2020 Jul;24(7):2477-2486. [Medline: $\underline{31701247]}$ [doi: 10.1007/s00784-019-03110-9]

48. Rompen E, Domken O, Degidi M, Pontes AE, Piattelli A. The effect of material characteristics, of surface topography and of implant components and connections on soft tissue integration: a literature review. Clin Oral Implants Res. 2006 Oct;17 Suppl 2:55-67. [Medline: 16968382] [doi: 10.1111/j.1600-0501.2006.01367.x]

49. Moraschini V, Luz D, Velloso G, Barboza EDP. Quality assessment of systematic reviews of the significance of keratinized mucosa on implant health. Int J Oral Maxillofac Surg. 2017 Jun;46(6):774-781. [Medline: 28292550] [doi: 10.1016/j.ijom.2017.02.1274]

50. Wennström JL, Derks J. Is there a need for keratinized mucosa around implants to maintain health and tissue stability? Clin Oral Implants Res. 2012 Oct;23 Suppl 6:136-46. [Medline: 23062138] [doi: 10.1111/j.1600-0501.2012.02540.x]

51. Chung DM, Oh TJ, Shotwell JL, Misch CE, Wang HL. Significance of keratinized mucosa in maintenance of dental implants with different surfaces. J Periodontol. 2006 Aug;77(8):1410-20. [Medline: 16881810] [doi: 10.1902/jop.2006.050393]

52. Jung RE, Fenner N, Hämmerle CH, Zitzmann NU. Long-term outcome of implants placed with guided bone regeneration (GBR) using resorbable and non-resorbable membranes after 12-14 years. Clin Oral Implants Res. 2013 Oct;24(10): 1065-73. [Medline: 22697628] [doi: 10.1111/j.1600-0501.2012.02522.x] 


\section{To cite this article:}

Hultin K, Eriksson A, Backe C, Johansson U, Bougas K.

A Pilot Study with Randomised Controlled Design Comparing TiZr Alloy Dental Implants to Ti Implants

J Oral Maxillofac Res 2020;11(4):e3

URL: http://www.ejomr.org/JOMR/archives/2020/4/e3/v11n4e3.pdf

doi: $\underline{10.5037 / \text { jomr.2020.11403 }}$

Copyright (C) Hultin K, Eriksson A, Backe C, Johansson U, Bougas K. Published in the JOURNAL OF ORAL \& MAXILLOFACIAL RESEARCH (http://www.ejomr.org), 31 Dcember 2020.

This is an open-access article, first published in the JOURNAL OF ORAL \& MAXILLOFACIAL RESEARCH, distributed under the terms of the Creative Commons Attribution-Noncommercial-No Derivative Works 3.0 Unported License, which permits unrestricted non-commercial use, distribution, and reproduction in any medium, provided the original work and is properly cited. The copyright, license information and link to the original publication on (http://www.ejomr.org) must be included. 